\title{
THE INFLUENCE OF BLOGGERS ON CONSUMER PURCHASE
}

\author{
Zehra Serman and Julian Sims \\ Birkbeck, University of London \\ Malet Street, London WCIE 7HX, UK
}

\begin{abstract}
This paper evaluates the impact of online blogging on buying intentions of customers. It begins by offering an overview of digital marketing. Next, it analyses the process of e-commerce and its relevance to modern business. Then there is an overview of digital marketing and the manner in which it has affected contemporary business. The paper then offers an insight into the construct of online blogging and how it is used by contemporary organizations. The paper also examines the manner in which blogs are being used for search engine optimization and content marketing to influence the buying behavior of consumers. Finally, the paper concludes by identifying a literature gap and the need to conduct further research work in this area.
\end{abstract}

\section{KEYWORDS}

Online Blogging, Customer Buying Behavior, SEO Optimization, Content Marketing, Marketing

\section{INTRODUCTION}

Business has undergone substantial change brought about by innovative technologies and globalization (Kannan 2017). The process of globalization can be seen as the single most important factor to change the nature of business (Urban, Gosline and Lee 2017). Contemporary businesses are increasingly engaging in internationalization and globalization. This has enhanced business competition by increasing the number of choices available to consumers (Kingsnorth 2016) and businesses are increasingly attempting to mitigate competition (Baltes,2015). Business prospects depend on the kind of strategies organizations deploy (Ho et al. 2015). Digital marketing strategies have a prominent role and firms are increasingly using digital marketing (Patrutiu-Baltes 2016).

This paper evaluates blogging as a form of digital marketing and the manner in which blogs influence consumer behavior. It highlights how blogging is used as a form of digital marketing. The paper suggests that effective use of blogging can aid promotion of products or services, contributing to firm success.

\section{MARKETING AND ITS IMPORTANCE}

The processes of marketing and promotion determine firm success or failure (Hsiao, Chang and Tang 2016). Firms deploy different kinds of marketing and promotional strategies to cascade the right kind of information to consumers. This act of offering relevant information to consumers is important: if consumers do not have appropriate information regarding products or services they are less likely to choose them (Ukpabi and Karjaluoto 2017). Consumers count on reliable and reputable sources while making purchase decision. Alsaleh (2017) finds that reputable bloggers with good social relations can establish a positive reputation that impacts consumer purchasing attitudes.

Blogs and social media tools positively affect consumers' purchase intentions. They help marketers to engage with customers and build strong customer relationships (Alsaleh 2017). In the past, firms used newspapers, radio and other means (Cheung, Xiao and Liu 2014), but these days many firms use digital marketing (Stephen 2016). This creates new opportunities, reducing costs and recent research suggests digital marketing leads to greater chances of success than traditional marketing (Lim, Cheah and Wong 2017). 


\section{E-COMMERCE AND ONLINE SHOPPING}

E-commerce creates more choice for customers (Schafer 2001). Having more choice increases the amount of information that customers need before they make purchase decisions. One way to overcome information overload is recommendations which provide: personalized product information; summarized community opinion; community critiques of products. Recommendations give customized personal experience (Schafer 2001). Reviews by existing customers, and the brand image of organizations and their products or services, plays a pivotal role in determining consumer buying decisions (Zhou et al. 2017).

\section{DIGITAL MARKETING}

The use of social media, Internet and other digital tools for marketing and promotion is cost effective compared to traditional forms of marketing and promotion (Cano, Doyle and Zhang 2018). Uzunoglu (2014) defines bloggers as "digital influencers" that have an impact on members of particular communities gathered around similar interests. Many studies find that face to face communication is not the only determinant of personal interaction: bloggers are also online opinion leaders (Uzunoglu 2014). Uzunoglu applies the two-step flow theory (Katz \& Lazarsfeld 2017) which suggests opinion leaders act as intermediaries in the web of social attraction: opinion leaders interpret the data they receive than pass it to others. This flow of information increases the influence among customers compared to mass media (Weimann 1994). Consequently, firms increasingly resort to digital marketing to enhance brand and online image, which in turn is directly related to the sale of products and services (Laroche et al. 2012).

\section{BLOGGING}

Blogging can be defined as the process by which individuals express their opinion over online media (Cheng and Fang 2015). Alsaleh (2017) defines blogs as writer's comments, brief texts, images and links structured in sequential order. Singer (2019) claims that approximately 900,000 articles are posted by bloggers every day. Twitter, Instagram and Facebook are examples of micro-blogging tools (Alsaleh 2017). Micro blogging increased by up to 62\% between 2009 and 2011 (Alsaleh, 2017). Customer experience affects purchasing intentions due to information accountability, and information accountability plays a vital role in enhancing consumer experiences: hence strengthening purchase intentions (Hsu Tsou, 2011).

Micro-blogs offer an overview of the reasons why consumers should choose products or services, and the key benefits they are likely to receive. Professional blogs also offer detailed information regarding products or services that firms will be launching in the future (Hwang and Jeong 2016). E-Commerce is expected to flourish in the future with the help of blogging and online reviews (Barrett, Oborn and Orlikowski 2016) and cross blog reviews by product experts of famous brands is another emerging marketing tool (Barret 2016).

\section{BLOGGING, SEO OPTIMIZATION, CONTENT MARKETING}

Content marketing is an important digital marketing strategy (Urban, Gosline and Lee 2017). There are two kinds of content marketing blogs: sponsored blogs and unsponsored blogs (Hsiao, Chang and Tang 2016). Firms publish sponsored blogs to promote their goods or services (Ukpabi and Karjaluoto 2017), enumerating the positive aspects. They help in the SEO optimization (Ho et al. 2015): the more positive reviews a firm has the better will be its online presence or brand image.

Bloggers of unsponsored blogs are not paid for the blog they write. They offer an unbiased or unprejudiced viewpoint (Liljander, Gummerus and Söderlund 2015). However, they also indirectly help in the process of content marketing (Hernández-Méndez, Muñoz-Leiva and Sánchez-Fernández 2015). For example, the greater number of keywords or product or service name one has in a directory, the higher that name will appear in Google search engine when consumers look up the name of the product, service or firm (Kim and Johnson 2016). This is important as many customers judge brand image on the basis of its position 
on the Google search list. Thus, the various kinds of online blogs directly influence the buying behavior of consumers by means articulating the positive and negative aspects of products and services, but also by helping search engine optimization.

\section{CUSTOMER BUYING BEHAVIOR}

Customer buying behavior can be defined as the conglomeration of the customer's preferences, attitudes, demands, needs and other attributes (Cheung, Xiao and Liu 2014). The business prospect of an organization depends on the effectiveness and efficiency with which it is able to take into consideration the attributes of the customer demographic on which they are focusing (Chen and Lin 2015). Thus firms regularly conduct marketing surveys and analysis to understand the needs of consumers (Lim, Cheah and Wong 2017).

Various theories and models relating to customer behavior have gained prominence. The "Theory of Reasoned Action" (Fishbein \& Ajzen 1975) is used to analyze consumer behavior (Baker, Donthu and Kumar 2016). According to this theory, individuals may develop beliefs by referring to information from normative practices of groups and peers. These beliefs influence individual behavior (Alsaleh 2017). Consequently, it can be hypothesized that "perceived usefulness of blogger recommendations will positively affect blog readers' attitudes toward purchasing products/services" (Alsaleh 2017).

"Motivation-Need Theory" (Maslow 1943) is also used for analysis of consumer behavior (Erkan and Evans 2018). Maslow's theory suggests that the primary motivation for consumers to opt for products or services is the extent to which the products or services are able to fulfill their requirements (Lu, Chang and Chang 2014). Blogs aspire to shed light on positive and negative aspects of products and services. Thus, regardless of the kind of blog, they take into consideration one kind of customer behavior theory or the other.

\section{IMPACT OF BLOGGING ON CUSTOMER BEHAVIOR}

The number of options available to consumers has increased due to number of firms offering similar products or services (Zhou et al. 2017). This has not only increased competition, but also made consumers more fickle than was previously the case. Consumers often opt for products or services which are best in quality and available at the lowest possible price (Chen et al. 2016), unlike earlier buying behavior when products or services were chosen on the basis of quality, customer loyalty or customer satisfaction.

Bloggers are very influential: $81 \%$ of consumers read recommendations through social websites before purchasing a product (Wegert 2010). Thus bloggers become opinion leaders. People can obtain knowledge about products and services, but also new trends in shopping and new places to visit. Consumers may be reviewing and checking the same blog daily over and over again (Alsaleh 2017). Alsaleh found 54\% of students reviewed blogs more than 10 times per day (Alsaleh 2017). This high level of commitment can be explained as a result of trust and reputation towards bloggers. Further studies verified that trust and reputation influence consumer purchase intentions to shop online (Chu Kamal 2008).

Consumers are influenced by online reviews written by bloggers as well as existing customers (Hsiao, Chang and Tang 2016). Firms use content marketing and SEO optimization to try to keep only the positive reviews on their official website and delete the negative (Liljander, Gummerus and Söderlund 2015). Recent research suggests this has a profound impact on consumer buying behavior (Patrutiu-Baltes 2016).

The decision of consumers to repeatedly opt for the products or services offered by a particular business depends on the kind of satisfaction offered to consumers (Urban, Gosline and Lee 2017). This in turn is directly related to the loyalty of consumers towards the products or services and organization. However, because of increasing competition, consumer loyalty has substantially decreased (Patrutiu-Baltes 2016). Firms are use blogs and bloggers to enhance their brand image because consumers opt for products or services of firms which have a positive brand image. It is precisely here that blogs become indispensable for firms as they are used for posting positive aspects of their organizations. Negative reviews or blogs also help (Ho et al. 2015) as they highlight the negative aspects or the drawbacks of the products or services, but also help content marketing and SEO optimization (Hsiao, Chang and Tang 2016). Thus, it can be said that blogs not only help firms influence consumer buying intention but also determine business prospects. 


\section{LITERATURE GAP}

Customer buying behavior and digital marketing has formed the central lacuna of numerous research works, but the concept of blogging and its use for influencing consumer buying intentions is a nascent one and there has been very little research on this topic. This paper evaluates the manner in which blogging can be utilized by firms to influence consumer behavior and serves as a framework for further research. The impact on buying behavior of negative perceptions from reading blogs also needs further study. With or without out real experience of a product, bloggers have the power to influence consumer perceptions and persuade them to buy or not buy products. Existing literature does not shed much light on these issues.

\section{CONCLUSION}

Consumer buying behavior has undergone substantial change in recent times due to the plethora of choices available to them, thus firms are using of different marketing strategies: one of the most important is blogging. Blogs offer various benefits to firms: SEO optimization, content marketing, highlighting positive aspects of products and services. These in turn have enabled organizations to positively affect the consumer buying behavior.

\section{REFERENCES}

Alsaleh,D (2017). Understanding the Role of Blogger Recommendations on Consumer Purchasing Behavior. The Journal of Business Inquiry 2017,17, Issue 1 (Special Issue), 23-40

Baker, A.M., Donthu, N. and Kumar, V., 2016. Investigating how word-of-mouth conversations about brands influence purchase and retransmission intentions. Journal of Marketing Research, 53(2), pp. 225-239.

Baltes, L.P., 2015. Content marketing-the fundamental tool of digital marketing. Bulletin of the Transilvania University of Brasov. Economic Sciences. Series V, 8(2), p. 111.

Barrett, M., Oborn, E. and Orlikowski, W., 2016. Creating value in online communities: The sociomaterial configuring of strategy, platform, and stakeholder engagement. Information Systems Research, 27(4), pp. 704-723.

Beck, K. and Ralph, J., 1994. Patterns Generates Architectures. Proceedings of European Conference of Object-Oriented Programming. Bologna, Italy, pp. 139-149.

Cano, M.B., Doyle, S. and Zhang, Y., 2018. Do Fashion Blogs Influence Vintage Fashion Consumption? An Analysis from the Perspective of the Chinese Market. In Vintage Luxury Fashion (pp. 167-183). Palgrave Macmillan, Cham.

Chen, J., Teng, L., Yu, Y. and Yu, X., 2016. The effect of online information sources on purchase intentions between consumers with high and low susceptibility to informational influence. Journal of Business Research, 69(2), pp. $467-475$.

Chen, S.C. and Lin, C.P., 2015. The impact of customer experience and perceived value on sustainable social relationship in blogs: An empirical study. Technological forecasting and social change, 96, pp. 40-50.

Cheng, R.J. and Fang, W., 2015. Blog intention based on fashion involvement and trust. International Journal of Electronic Commerce Studies, 6(1), pp. 19-36.

Cheung, C.M., Xiao, B.S. and Liu, I.L., 2014. Do actions speak louder than voices? The signaling role of social information cues in influencing consumer purchase decisions. Decision Support Systems, 65, pp. 50-58.

Daunt, K.L., Greer, D.A., Pancer, E., McShane, L. and Poole, M., 2017. The Dark Side of Marketing. Journal of Marketing Management, 33(15-16).

Ebru Uzunoglu, S. M. (2014). Brand communication through digital influencers: Leveraging bloggerengagement. Izmir: International Journal of Information Management 34.

Erkan, I. and Evans, C., 2018. Social media or shopping websites? The influence of eWOM on consumers' online purchase intentions. Journal of Marketing Communications, 24(6), pp. 617-632.

Fishbein, M., \& Ajzen, I. Belief, attitude, intention andbehavior: An introduction to theory and research.Reading, Mass.: Addison-Wesley, 1975

Hernández-Méndez, J., Muñoz-Leiva, F. and Sánchez-Fernández, J., 2015. The influence of e-word-of-mouth on travel decision-making: consumer profiles. Current issues in tourism, 18(11), pp. 1001-1021. 
Ho, C.H., Chiu, K.H., Chen, H. and Papazafeiropoulou, A., 2015. Can internet blogs be used as an effective advertising tool? The role of product blog type and brand awareness. Journal of Enterprise Information Management, 28(3), pp. 346-362.

Hsiao, C.H., Chang, J.J. and Tang, K.Y., 2016. Exploring the influential factors in continuance usage of mobile social Apps: Satisfaction, habit, and customer value perspectives. Telematics and Informatics, 33(2), pp. 342-355

Hsu, C.L., Chuan-Chuan Lin, J. and Chiang, H.S., 2013. The effects of blogger recommendations on customers' online shopping intentions. Internet Research, 23(1), pp. 69-88.

Hwang, Y. and Jeong, S.H., 2016. "This is a sponsored blog post, but all opinions are my own": The effects of sponsorship disclosure on responses to sponsored blog posts. Computers in Human Behavior, 62, pp. 528-535.

Kannan, P.K., 2017. Digital marketing: A framework, review and research agenda. International Journal of Research in Marketing, 34(1), pp. 22-45.

Katz, E., Lazarsfeld, P. F., \& Roper, E. (2017). Personal influence: The part played by people in the flow of mass communications. Routledge.

Kim, A.J. and Johnson, K.K., 2016. Power of consumers using social media: Examining the influences of brand-related user- generated content on Facebook. Computers in Human Behavior, 58, pp. 98-108.

Kingsnorth, S., 2016. Digital marketing strategy: an integrated approach to online marketing. Kogan Page Publishers.

Laroche, M., Habibi, M.R. and Richard, M.O., 2013. To be or not to be in social media: How brand loyalty is affected by social media?. International Journal of Information Management, 33(1), pp. 76-82.

Laroche, M., Habibi, M.R., Richard, M.O. and Sankaranarayanan, R., 2012. The effects of social media based brand communities on brand community markers, value creation practices, brand trust and brand loyalty. Computers in Human Behavior, 28(5), pp. 1755-1767.

Liljander, V., Gummerus, J. and Söderlund, M., 2015. Young consumers' responses to suspected covert and overt blog marketing. Internet Research, 25(4), pp. 610-632.

Lim, X.J., Cheah, J.H. and Wong, M.W., 2017. The Impact of Social Media Influencers on Purchase Intention and the Mediation Effect of Customer Attitude. Asian Journal of Business Research, 7(2), p. 19.

Lu, L.C., Chang, W.P. and Chang, H.H., 2014. Consumer attitudes toward blogger's sponsored recommendations and purchase intention: The effect of sponsorship type, product type, and brand awareness. Computers in Human Behavior, 34, pp. 258-266.

Maslow, A. H. (1943). A theory of human motivation. Psychological review, 50(4), 370.

Ngai, E.W., Tao, S.S.and Moon, K.K., 2015. Social media research: Theories, constructs, and conceptual frameworks. International Journal of Information Management, 35(1), pp. 33-44.

Patrutiu-Baltes, L., 2016. Inbound Marketing-the most important digital marketing strategy. Bulletin of the Transilvania University of Brasov. Economic Sciences. Series V, 9(2), p. 61.

Ryan, D., 2016. Understanding digital marketing: marketing strategies for engaging the digital generation. Kogan Page Publishers.

Schafer, J. B. (2001). E- commerce Reccomandation Applications. Data Mining and Knowledge Discovery,5 115-153.

Stephen, A.T., 2016. The role of digital and social media marketing in consumer behavior. Current Opinion in Psychology, 10, pp. 17-21.

Ukpabi, D.C. and Karjaluoto, H., 2017. Consumers' acceptance of information and communications technology in tourism: A review. Telematics and Informatics, 34(5), pp. 618-644.

Urban, G.L., Gosline, R. and Lee, J., 2017. The Power of Consumer Stories in Digital Marketing. MIT Sloan Management Review, 58(4).

Weimann, G. (1994). The influentials: People who influence people. SUNY Press.

Zhou, X., Song, Q., Li, Y.Y., Tan, H. and Zhou, H., 2017. Examining the influence of online retailers' micro-blogs on consumers' purchase intention. Internet Research, 27(4), pp. 819-838. 